\title{
Coronavirus disease and male fertility: a systematic review
}

\author{
Mobina Fathi ${ }^{1}$, Kimia Vakili ${ }^{1}$, Abbas Aliaghaei ${ }^{2}$, Shahrzad Nematollahi ${ }^{3}$, Tahmineh Peirouvi ${ }^{4^{*}}$ and \\ Ali Shalizar-Jalali ${ }^{5}$ (D)
}

\begin{abstract}
Background: Based on the information from other SARS-CoV infections in the patients recovered from COVID-19, particularly cases in the reproductive age, gonadal function evaluation and andrological consultation comprising semen analysis are recommended.

Main body: Based on the COVID-19 infected patients' seminal fluid analyses, SARS-CoV-2 may employ the male reproductive system as a transmission pathway. It has been also demonstrated that angiotensin-converting enzyme 2 (ACE2) can be strongly expressed at the protein levels in the testicular cells. The high expression of ACE2 in testes suggests that testes in the COVID-19 infected males can have an important role in the viral persistence and this subject needs further investigations. Several researchers have examined males recovered from COVID-19, but still, large-scale experiments are needed to determine the effects of SARS-CoV-2 on the male reproductive system as well as viral transmission risk.
\end{abstract}

Conclusion: Comprehensive researches are required to figure out the presence of the SARS-CoV-2 virus in seminal fluid as well as its sexual transmissibility and impact on sperm characteristics.

Keywords: Coronavirus disease, Angiotensin-converting enzyme, Testis, Sperm, Male fertility

\section{Background}

The World Health Organization has announced coronavirus disease 2019 (COVID-19) as a global pandemic since March 11, 2020 [1]. The pandemic, also known as the SARS-CoV-2 pandemic, has imposed huge pressure on health care systems around the world along with negative social and economic consequences [2]. Although the precise effects of SARS-COV-2 on the urinary tract have not yet been identified, this does not mean that urinary specialists will not investigate about this subject [3].

In order to restrict the spread of the COVID-19 pandemic, investigations on the transmission routes and mechanisms are extensively conducted. The SARS-CoV2 mainly transmits through respiratory droplets [4] and has been also observed in different biological fluids

\footnotetext{
* Correspondence: tpeirouvi@yahoo.co.uk

${ }^{4}$ Department of Histology and Embryology, Faculty of Medicine, Urmia

University of Medical Sciences, Urmia, Iran

Full list of author information is available at the end of the article
}

including blood, urine, and feces [5]. The presence of SARS-CoV-2 in genital secretions has not been confirmed yet. Due to the blood-testis barrier (BTB), testis is partially immune to many microorganisms [6]; however, some viruses such as the mumps virus have the ability to cross the BTB and cause localized testis inflammation in forms of orchitis [7]. On the other hand, angiotensin-converting enzyme 2 (ACE2) and viral spike (S) protein, the mediators for SARS-COV-2 entrance into the target cells, mainly exist in human testis $[8,9]$. These observations have raised concerns over the possibility of sexual transmission of COVID-19 [10], although the evidence is largely insufficient [11].

Confirmation about the existence of SARS-CoV-2 in the seminal fluid would bear new and serious reproductive and sexual insights into this pandemic $[12,13]$.

The present study aimed to review the evidence regarding presence of SARS-CoV-2 in seminal fluid and to define the expression profile of trans-membrane

\section{Springer Open}

(c) The Author(s). 2021 Open Access This article is licensed under a Creative Commons Attribution 4.0 International License, which permits use, sharing, adaptation, distribution and reproduction in any medium or format, as long as you give appropriate credit to the original author(s) and the source, provide a link to the Creative Commons licence, and indicate if changes were made. The images or other third party material in this article are included in the article's Creative Commons licence, unless indicated otherwise in a credit line to the material. If material is not included in the article's Creative Commons licence and your intended use is not permitted by statutory regulation or exceeds the permitted use, you will need to obtain permission directly from the copyright holder. To view a copy of this licence, visit http://creativecommons.org/licenses/by/4.0/. 
protease, serine 2 (TMPRSS2), and ACE2 in human testes to provide beneficial insights into the viral entry and the early impacts of the virus on male reproductive functions. This systematic review will shed light on the possibility of SARS-CoV-2 transmission through semen and reproductive complications following infection, which might influence fertility in young COVID-19 patients.

\section{Main text}

The present study aimed to systematically review the current literature regarding the presence of SARS-CoV-2 in seminal fluids. International scientific databases including Scopus, Web of Science, and MEDLINE as well as national databases including Meh Iran, SID, and Iran Doc were reviewed with the following keywords: SARS-CoV-2, COVID-19, coronavirus, ACE, angiotensin II, angiotensinconverting enzyme 2, Ang-(1-7), testes, male reproductive system, male fertility, and semen. Inclusion criteria were defined as all published papers in Persian or English languages that studied the presence of coronavirus in seminal fluids of the male human host. Exclusion criterion was defined for articles that assessed types of coronaviruses other than SARS-CoV-2. Selection of papers was performed by one researcher, while the second researcher reviewed the records to exclude duplicates. After reviewing titles of 51 studies, 15 were removed due to non-human subjects. Finally, data of 36 papers including author information, study location, virus detection method, and study findings were extracted by two independent researchers (Fig. 1). Due to the huge variability in the study findings and methods, we could not perform meta-analysis in the included studies.

\section{Angiotensin-converting enzyme 2 expression in testes}

The SARS-CoV2 enters host cells through a complex process, starting with the interaction of its spike protein with ACE2 $[8,14]$. The ACE2 is a monocarboxypeptidase, converting angiotensin II to angiotensin 1-7. These factors (angiotensin 1-7) can stimulate MAS receptors and antagonize the effects of angiotensin I [15].

The SARS-CoV-2 shares $80 \%$ sequence homology and cell adhesion via ACE2 with another coronavirus, SARS-CoV being responsible for SARS outbreak in 2003 [16]. However, SARS-CoV-2 has some distinct characteristics increasing its clinical virulence. For instance, a more compact configuration in the three-

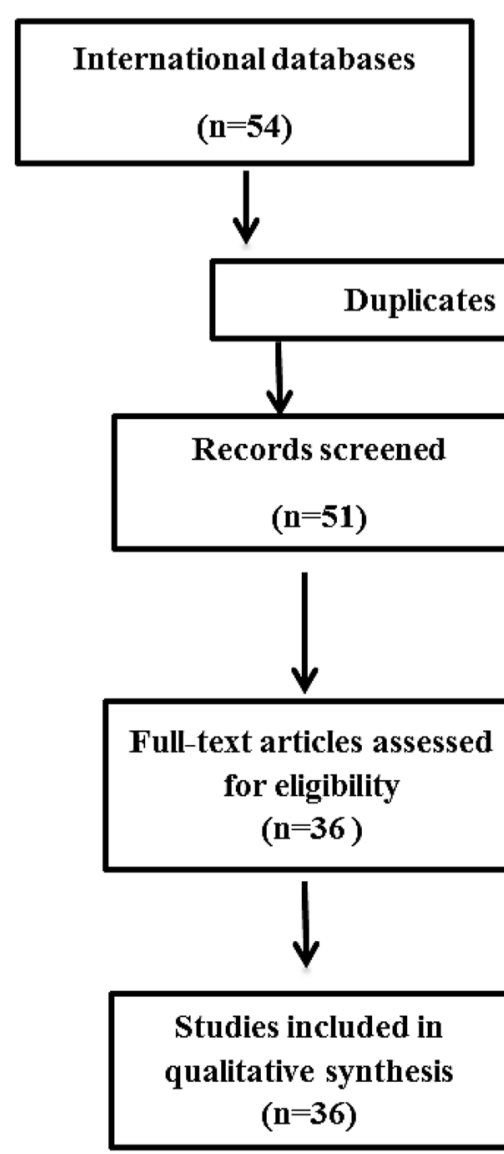

Fig. 1. Diagram of included studies into the systematic review 
dimensional structure of this virus enhances its binding affinity to ACE2 as a viral receptor. Additionally, SARS-CoV-2 has a polybasic cleavage site increasing its viral internalization into the cells. According to these unique features of SARS-CoV-2, the stronger virulence of this virus compared to previous coronaviruses is partially justifiable [17].

The ACE2 has a high expression level in various human tissues and organs including lung alveolar epithelial cells, small intestinal epithelial cells, vascular endothelial cells, smooth muscle cells, brush border of proximal tubular cells, and parietal epithelial cells in kidneys and oral and nasal mucosae [18]. Moreover, ACE2 is highly expressed in human testes. Specifically, ACE2 is expressed in seminiferous tubules cells along with Leydig and Sertoli cells in testes, which might be associated with potential COV infection in the reproductive system [19]. Interestingly, ACE2 expression in testes is agedependent. Accordingly, the highest and lowest expressions of ACE2 occur in patients aged 30 and 60, respectively [20]. Another probable cause for localization of SARS-CoV-2 in the male reproductive system can be the expression by furin domains in human's epididymis, as described above [21].

It has been proved that cells expressing TMPRSS2 for $S$ protein (which can initiate the viral internalization process) on their surface have enhanced SARS-CoV-2 isolation [14]. The TMPRSS2 is highly expressed in the epithelial cells of the human prostate gland, especially, in the apical surface of the luminal cells. The expression of TMPRSS2 is controlled by androgens (the promoter enhancers of the TMPRSS2 gene). The TMPRSS2 can be released into semen via proteasomes, which are vesicles that may help sperms to have better function [22]. The high TMPRSS2 expression in the prostate can be related to COV infection and another point of weakness of the male reproductive system.

\section{The presence of the SARS-CoV-2 virus in the semen and testis}

If SARS-CoV-2 employs SARS-CoV receptor ACE2 to enter the cell, TMPRSS2 is repairing this process and thus, the advanced separation of SARS-CoV-2 in the cells expressing TMPRSS2 may occur [13]. High expression of TMPRSS2 is observed in prostate epithelial cells and includes the apical plasma membrane of luminal cells located in the prostate. Its expression can be regulated by androgens, which seems to be enhancers of the gene and additionally could be released into the semen as a component of proteasomes. It also has the ability to improve male reproduction ability and to enhance the sperm's function [22].

The presence of SARS-CoV-2 in sperm and seminal fluid and the likelihood of COVID-19 transmission through sexual intercourse need to be investigated. Despite observed considerable damage to seminiferous tubules and Sertoli cells, mild inflammation in the interstitium, and reduction in the Leydig cell population [23], attempts to find signs of SARS-CoV-2 in seminal fluid have resulted in contradictory findings [24].

The SARS-CoV-2 may influence the production of luteinizing hormone, follicle-stimulating hormone, and testosterone as well as the testes [25]. In one small-scale study, SARS-CoV-2 was detected in semen in $26.70 \%$ of COVID-19 patients in the acute phase and $8.70 \%$ of the patients in the recovery phase [26]. On the other hand, failure to detect SARS-CoV-2 in the seminal fluid of patients in clinical or recovery phases of COVID-19 is frequently reported $[21,27]$. Search for SARS-CoV-2 in the seminal fluid of asymptomatic or deceased COVID-19 patients also did not lead to any promising findings [23, 28]. The different findings among studies might partially be attributed to various phases of disease course, clinical condition of patients, and detection method such as RTPCR and electron microscopy.

\section{SARS-CoV-2 and testis: similarity with SARS}

As stated before, SARS-CoV-2 shares a lot of mutual characteristics with SARS-CoV. In 2003, orchitis (inflammation of the testicles) was considered as a complication in SARS patients [29] following a study on six cases with SARS-associated fatal orchitis. Several mechanisms have been proposed to explain the underlying cause of testicular damage in SARS patients, which can logically be applicable to the SARS-CoV-2 as well. These hypotheses are as follow:

1) The ideal temperature for spermatogenesis is $1-8$ ${ }^{\circ} \mathrm{C}$ lower than regular human body temperature (37 $\left.{ }^{\circ} \mathrm{C}\right)$. Long-term fever can lead to increased testicular temperature and cause germ cells destruction and degeneration. According to previous studies, high temperature can also result in germ cells apoptosis [30]. High fever is frequently reported in both SARS and COVID-19 patients. Therefore, it might have a direct effect on testicular destruction.

2) Steroids are one of the medication options for SARS and COVID-19 patients, despite their clinical efficacy is still debating [31]. However, previous evidence did not support this hypothesis, as one of the cases who had not received glucocorticoid developed orichitis in the same way as others [29].

3) Viruses may also be able to directly infect testis. Considering the earlier discussion about the role of ACE2 in viral entrance of SARS-CoV and SARS$\mathrm{CoV}-2$, infection of testis by viruses seems plausible. However, studies have represented conflicting results about possibility of direct SARS virus infection 




Fig. 2. Possible mechanisms of COVID-19-induced testicular damage

in testis. According to $\mathrm{Xu}$ et al., none of six cases represented signs of direct infection in their testes [29]. While in the study conducted by Zhao et al., SARS-CoV was present in Leydig and testicular germ cells [32]. As SARS-CoV-2 enters host cells via ACE2, the risk of direct testicular infection exists in COVID-19 patients; however, the evidence is not found yet.

4) Leukocyte infiltration in testis can interfere with the Leydig cells' normal function and testosterone production and then lead to BTB damage and seminiferous epithelium destruction. Leukocytes can also lead to autoantibody development and autoimmune responses in seminiferous tubules via inflammatory cytokines releasing [29]. Increase of serum IgG levels is reported in both SARS and COVID-19 patients [33]. Therefore, SARS-CoV and SARS-CoV-2 may be able to trigger secondary autoimmune responses in testis and cause autoimmune orchitis.

5) Viral infections result in redox homeostasis disruption in the body leading to reactive oxygen species (ROS) over-production building an ideal situation for viral replication [34]. In line with that, coronavirus infections such as SARS-CoV and SARS-CoV-2 can cause male reproductive dysfunction through ROS over-generation and apoptotic pathways activation $[35,36]$.

\section{Conclusions}

Testicular damage has been reported following SARSCoV-2 infection, while clinical damage of the virus is theoretically possible. The hypothetical mechanisms for this damage include direct viral invasion to testicular tissue through ACE2 receptors, temperature-related testicular damage as a result of persistent high fever, secondary inflammatory and autoimmune responses, unexpected side effects of COVID-19 medications such as steroids, and viral infection-related oxidative stress (Fig. 2). On the other hand, clinical and epidemiological evidence regarding the effects of COVID-19 on reproductive health and future infertility of male patients is hugely scarce. As COVID-19 is a newly emerged disease, further follow-up studies on reproductive outcomes of recovered patients (especially those who are of reproductive age) are recommended to investigate probable long-term consequences.

\section{Abbreviations}

ACE2: Angiotensin-converting enzyme 2; COVID-19: Coronavirus disease 2019; BTB: Blood-testis barrier; TMPRSS2: Transmembrane protease, serine 2; ROS: Reactive oxygen species

\section{Acknowledgements}

None

Authors' contributions

Drafting of the manuscript: MF, KV, AA, and SN. Study concept and design: TP. Critical revision of the manuscript: ASJ. All authors have read and approved the manuscript.

Funding

None

Availability of data and materials

Not applicable

\section{Declarations}

Ethics approval and consent to participate Not applicable

\section{Consent for publication \\ Not applicable}

\section{Competing interests}

The authors declare that they have no competing interests.

\section{Author details}

${ }^{1}$ Student Research Committee, Faculty of Medicine, Shahid Beheshti University of Medical Sciences, Tehran, Iran. ${ }^{2}$ Faculty of Medicine, Shahid Beheshti University of Medical Sciences, Tehran, Iran. ${ }^{3}$ Men's Health and Reproductive Health Research Center, Shahid Beheshti University of Medical 
Sciences, Tehran, Iran. ${ }^{4}$ Department of Histology and Embryology, Faculty of Medicine, Urmia University of Medical Sciences, Urmia, Iran. ${ }^{5}$ Department of Basic Sciences, Faculty of Veterinary Medicine, Urmia University, Urmia, Iran.

Received: 12 May 2021 Accepted: 5 August 2021

Published online: 16 August 2021

\section{References}

1. Chauhan S (2020) Comprehensive review of coronavirus disease 2019 (COVID-19). Biomed J 43(4):334-340. https://doi.org/10.1016/j.bj.2020.05.023

2. Nicola M, Alsafi Z, Sohrabi C, Kerwan A, Al-Jabir A, losifidis C, Agha M, Aghaf $R$ (2020) The socio-economic implications of the coronavirus pandemic (COVID-19): a review. Int J Surg 78:185-193. https://doi.org/10.1016/.jijsu.202 0.04 .018

3. Fu L, Wang B, Yuan T, Chen X, Ao Y, Fitzpatrick T, Li P, Zhou Y, Lin Y, Duan Q, Luo G, Fan S, Lu Y, Feng A, Zhan Y, Liang B, Cai W, Zhang L, Du X, Li L, Shu Y, Zou H (2020) Clinical characteristics of coronavirus disease 2019 (COVID-19) in China: a systematic review and meta-analysis. J Infect 80(6): 656-665. https://doi.org/10.1016/j.jinf.2020.03.041

4. Hui DSC, Zumla A (2019) Severe acute respiratory syndrome: historical, epidemiologic, and clinical features. Infect Dis Clin North Am 33(4):869-889. https://doi.org/10.1016/j.idc.2019.07.001

5. Holshue ML, DeBolt C, Lindquist S, Lofy KH, Wiesman J, Bruce H, Spitters C, Ericson K, Wilkerson S, Tural A, Diaz G, Cohn A, Fox LA, Patel A, Gerber SI, Kim L, Tong S, Lu X, Lindstrom S, Pallansch MA, Weldon WC, Biggs HM, Uyeki TM, Pillai SK (2020) First case of 2019 novel coronavirus in the United States. New Engl J Med 382(10):929-936. https://doi.org/10.1056/NEJMoa2 001191

6. Cheng CY, Mruk DD (2012) The blood-testis barrier and its implications for male contraception. Pharmacol Rev 64(1):16-64. https://doi.org/10.1124/ pr.110.002790

7. Chen Y, Guo Y, Pan Y, Zhao ZJ (2020) Structure analysis of the receptor binding of 2019-nCoV. Biochem Biophys Res Comm 525(1):135-140. https:// doi.org/10.1016/j.bbrc.2020.02.071

8. Zhou P, Yang X-L, Wang X-G, Hu B, Zhang L, Zhang W, Si H-R, Zhu Y, Li B, Huang C-L, Chen H-D, Chen J, Luo Y, Guo H, Jiang R-D, Liu M-Q, Chen Y, Shen X-R, Wang X, Zheng X-S, Zhao K, Chen Q-J, Deng F, Liu L-L, Yan B, Zhan F-X, Wang Y-Y, Xiao G-F, Shi Z-L (2020) A pneumonia outbreak associated with a new coronavirus of probable bat origin. Nature 579(7798): 270-273. https://doi.org/10.1038/s41586-020-2012-7

9. Li W, Moore MJ, Vasilieva N, Sui J, Wong SK, Berne MA, Somasundaran M, Sullivan JL, Luzuriaga K, Greenough TC, Choe H, Farzan M (2003) Angiotensin-converting enzyme 2 is a functional receptor for the SARS coronavirus. Nature 426(6965):450-454. https://doi.org/10.1038/nature02145

10. Song, C, Wang Y, Li W, Hu B, Chen G, Xia P, Wang W, Li C, Hu Z, Yang X, Yao B, Liu Y (2020) Detection of 2019 novel coronavirus in semen and testicular biopsy specimen of COVID-19 patients. medRxiv. https://doi.org/1 0.1101/2020.03.31.20042333

11. Pan F, Xiao X, Guo J, Song Y, Li H, Patel DP, Spivak AM, Alukal JP, Zhang X, Xiong C, Li PS, Hotaling JM (2020) No evidence of severe acute respiratory syndrome-coronavirus 2 in semen of males recovering from coronavirus disease 2019. Fertil Steril 113(6):1135-1139. https://doi.org/10.1016/j. fertnstert.2020.04.024

12. Aversa A, Jannini EA (2020) COVID-19, or the triumph of monogamy? Minerva Endocrinol 45(2): 77-8. https://doi.org/10.23736/S0391-1977.20.032 07-1

13. Corona G, Baldi E, Isidori AM, Paoli D, Pallotti F, De Santis L, Francavilla F, La Vignera S, Selice R, Caponecchia L, Pivonello R, Ferlin A, Foresta C, Jannini EA, Lenzi A, Maggi M, Lombardo F (2020) SARS-CoV-2 infection, male fertility and sperm cryopreservation: a position statement of the Italian Society of Andrology and Sexual Medicine (SIAMS) (Società Italiana di Andrologia e Medicina della Sessualità). J Endocrinol Invest 27(8):1-5. https://doi.org/10.1007/s40618-020-01290-w

14. Hoffmann M, Kleine-Weber H, Schroeder S, Krüger N, Herrler T, Erichsen S, Schiergens TS, Herrler G, Wu N-H, Nitsche A, Müller MA, Drosten C, Pöhlmann S (2020) SARS-CoV-2 cell entry depends on ACE2 and TMPRSS2 and is blocked by a clinically proven protease inhibitor. Cell 181(2):271-280. https://doi.org/10.1016/j.cell.2020.02.052

15. Patel VB, Zhong J-C, Grant MB, Oudit GY (2016) Role of the ACE2/ angiotensin 1-7 axis of the renin-angiotensin system in heart failure. Circ Res 118(8):1313-1326. https://doi.org/10.1161/CIRCRESAHA.116.307708
16. Mao L, Jin H, Wang M, Hu Y, Chen S, He Q, Chang J, Hong C, Zhou Y, Wang D, Miao X, Li Y, Hu B (2020) Neurologic manifestations of hospitalized patients with coronavirus disease 2019 in Wuhan, China. JAMA Neurol 77(6): 683-690. https://doi.org/10.1001/jamaneurol.2020.1127

17. Fani M, Teimoori A, Ghafari S (2020) Comparison of the COVID-2019 (SARSCoV-2) pathogenesis with SARS-CoV and MERS-CoV infections. Future Virol. https://doi.org/10.2217/fvl-2020-0050, 15, 5, 317, 323

18. Bourgonje AR, Abdulle AE, Timens W, Hillebrands J-L, Navis GJ, Gordijn SJ, Bolling MC, Dijkstra G, Voors AA, Osterhaus AD, van der Voort PH, Mulder DJ, van Goor H (2020) Angiotensin-converting enzyme-2 (ACE2), SARS-CoV2 andpathophysiology of coronavirus disease 2019 (COVID-19). Journal Pathol 251(3):228-248. https://doi.org/10.1002/path.5471

19. Wang $Z, X u X(2020)$ scRNA-seq profiling of human testes reveals the presence of the ACE2 receptor, a target for SARSCOV-2 infection in spermatogonia, Leydig and Sertoli cells. Cells 9(4):920. https://doi.org/10.33 90/cells9040920, 9, 4

20. Shen Q, Xiao X, Aierken A, Yue W, Wu X, Liao M, Hua J (2020) The ACE2 expression in Sertoli cells and germ cells may cause male reproductive disorder after SARS-CoV-2 infection. J Cell Mol Med 24(16):9472-9477.https:// doi.org/10.1111/jcmm.15541

21. Thimon V, Belghazi M, Dacheux J-L, Gatti J-L (2006) Analysis of furin ectodomain shedding in epididymal fluid of mammals: demonstration that shedding of furin occurs in vivo. Reproduction 132(6):899-908. https://doi. org/10.1530/REP-06-0077

22. Chen Y-W, Lee M-S, Lucht A, Chou F-P, Huang W, Havighurst TC, Kim KM, Wang J-K, Antalis TM, Johnson MD, Lin C-Y (2010) TMPRSS2, a serine protease expressed in the prostate on the apical surface of luminal epithelial cells and released into semen in prostasomes, is misregulated in prostate cancer cells. Am J Pathol 176(6):2986-2996. https://doi.org/10.23 53/ajpath.2010.090665

23. Yang M, Chen S, Huang B, Zhong J-M, Su H, Chen Y-J, Cao Q, Ma L, He J, Li X-F, Li X, Zhou J-J, Fan J, Luo D-J, Chang X-N, Arkun K, Zhou M, Nie X (2020) Pathological findings in the testes of COVID-19 patients: clinical implications. Eur Urol Focus 6(5):1124-1129. https://doi.org/10.1016/..euf.202 0.05 .009

24. Sharun K, Tiwari R, Dhama K (2020) SARS-CoV-2 in semen: potential for sexual transmission in COVID-19. Int J Surg 84:156-158. https://doi.org/10.1 016/j.jijsu.2020.11.011

25. Ma L, Xie W, Li D, Shi L, Mao Y, Xiong Y, Zhang Y, Zhang M (2020) Effect of SARS-CoV-2 infection upon male gonadal function: a single center-based study. medRxiv. https://doi.org/10.1101/2020.03.21.20037267

26. Li D, Jin M, Bao P, Zhao W, Zhang S (2020) Clinical characteristics and results of semen tests among men with coronavirus disease 2019. JAMA Netw Open 3(5):e208292. https://doi.org/10.1001/jamanetworkopen.2020.8292

27. Perry MJ, Arrington S, Neumann LM, Carrell D, Mores CN (2020) It is currently unknown whether SARS-CoV-2 is viable in semen or whether COVID-19 damages sperm. Andrology, https://doi.org/10.1111/andr.12831 9(1):30-32

28. Paoli D, Pallotti F, Colangelo S, Basilico F, Mazzuti L, Turriziani O, Antonelli G, Lenzi A, Lombardo F (2020) Study of SARS-CoV-2 in semen and urine samples of a volunteer with positive naso-pharyngeal swab. J Endocrinol Invest 43(12):1-4. https://doi.org/10.1007/s40618-020-01261-1

29. Xu J, Qi L, Chi X, Yang J, Wei X, Gong E, Peh S, Gu J (2006) Orchitis: a complication of severe acute respiratory syndrome (SARS). Biol Reprod 74(2):410-416. https://doi.org/10.1095/biolreprod.105.044776

30. Oliver RT (1990) Atrophy, hormones, genes and viruses in aetiology germ cell tumours. Cancer Surv 9(2):263-286

31. Zha L, Li S, Pan L, Tefsen B, Li Y, French N, Chen L, Yang G, Villanueva EV (2020) Corticosteroid treatment of patients with coronavirus disease 2019 (COVID-19). Med J Aust 212(9):416-420. https://doi.org/10.5694/ mja2.50577

32. Zhao J, Zhou G, Sun Y, Wang S, Yang J, Meng E, Pan D, Li W, Zhou X, Wang Y, Lu J, Li N, Wang D, Zhou B, Zhang T (2003) Clinical pathology and pathogenesis of severe acute respiratory syndrome. Zhonghua Shi Yan He Lin Chuang Bing Du Xue Za Zhi 17(3):217-221

33. Ma H, Zeng W, He H, Zhao D, Jiang D, Zhou P, Cheng L, Li Y, Ma X, Jin T (2020) Serum IgA, IgM, and IgG responses in COVID-19. Cell Mol Immunol 17(7):773-775. https://doi.org/10.1038/s41423-020-0474-z

34. Checconi P, DeAngelis M, Marcocci ME, Fraternale A, Magnani M, Palamara AT, Nencioni L (2020) Redox-modulating agents in the treatment of viral infections. Int J Mol Sci 21(11):4084. https://doi.org/10.3390/ijms21114084 
35. Maleki BH, Tartibian B (2021) COVID-19 and male reproductive function: a prospective, longitudinal cohort study. Reproduction 161(3):319-331. https://doi.org/10.1530/REP-20-0382

36. Moghimi N, Farsani BE, Ghadipasha M, Mahmoudiasl G, Piryaei A, Aliaghaei A, Abdi S, Abbaszadeh H, Abdollahifar M, Forozesh M (2021) COVID-19 disrupts spermatogenesis through the oxidative stress pathway following induction of apoptosis. Apoptosis 26(7-8):415-430. https://doi.org/10.1007/ s10495-021-01680-2

\section{Publisher's Note}

Springer Nature remains neutral with regard to jurisdictional claims in published maps and institutional affiliations.

\section{Submit your manuscript to a SpringerOpen ${ }^{\circ}$ journal and benefit from:}

- Convenient online submission

- Rigorous peer review

- Open access: articles freely available online

- High visibility within the field

- Retaining the copyright to your article

Submit your next manuscript at $\boldsymbol{\nabla}$ springeropen.com 